ORIGINAL PROF-2143

\title{
EPIDEMIOLOGY OF AMPUTATION;
}

Low resource community: Sindh Province, Pakistan (october 2007- june2012).

Dr. Nabila Soomro, Rukhsana Bibi, Dr. Syed Imran Ahmed, Brigitte Kamran, Muhammad Ali Minhas, Kamran Yousuf Siddiqui

ABSTRACT... Amputation is stated to be a foremost but preventable community health problem causing intense financial, social and emotional effects on the patient and family particularly in developing countries where the prosthetic services are limited. The purpose of this study was to identify the causes and levels of amputation in low resource community, Sindh Pakistan. Methods: This was a retrospective chart review study that was carried out at first civilian Institute of physical medicine \& rehabilitation-Dow University of health sciences from October 2007 to June 2012. After verbal informed consent all patients, who underwent major or minor amputation were enrolled for the study. Data was collected using a pre-tested, coded questionnaire and analysed using SPSS version 16. Results: A total of 1115 patients were enrolled into the study. Their ages were ranged between 2-95 years (mean 38.40 \pm 17.38 ). Among total population of amputees $83.58 \%$ were males. The most common cause for major limb amputation was road Traffic accident $38.38 \%$, followed by Diabetes $15.42 \%$, infection $14.26 \%$ and trauma $12.37 \%$. Lower limbs (trans-tibial) amputations were in $47.35 \%$ of cases and transfemoral in $27.98 \%$ of cases. While for the upper limb trans-radial amputation (7.4\%) were found to be more common than trans-humeral (5.56\%). Other amputations were for shoulder, hip and knee disarticulations. Conclusions: Road traffic accidents, complications of diabetic foot ulcers, infections and trauma were the most common causes for major limb amputations found in low resource community, Sindh Pakistan. The majority of these amputations are preventable by endowment of traffic rules, health education, early preventions and appropriate management of the common infections.

Key words: Amputation, low resource community, levels of amputation, causes of amputation.

Article Citation

Soomro N, Bibi R, Ahmed SI, Kamran B, Minhas MA, Siddiqui KY. Epidemiology of amputation; low resource community: Sindh Province, Pakistan. Professional Med J 2013;20(2): 261-265.

\section{INTRODUCTION}

An amputation is a surgical procedure for the removal of a limb when limb recovery is impossible or when the limb is dead or nonfunctional risking the patient's life. It has been a public health problem and is still often perceived as failure of treatment but it can be the choice of treatment for severe trauma, vascular disease and tumor resection.

Globally the rate of amputation has been on rise due to accidents, gun- shot injuries, vascular diseases, diabetes, terrorist attack and earthquakes ${ }^{1,2}$. Widerange of studies have been conducted throughout the world, the first ever World report on disability, produced jointly by WHO and the World Bank suggests that more than a billion people in the world today experience disability (June 2011, WHO) and suggested rehabilitation options ${ }^{3}$.

In the United States, there are approximately 1.7 million people living with limb loss. It is estimated that one out of every 200 people in the U.S. has had an amputation $^{5,6}$ and during 1988 to 1996, there were an average of 133,735 hospital discharges due to amputation per year?

The major determinants of amputation in most of the studies among low resource developing countries have been peripheral vascular disease in $25-50 \%$ of cases the other researches conducted by Warren and Kihn (1968), Burgess (1969) and Kerstein (1974) reported $75-85 \%$ cases of lower limb amputation due to peripheral vascular diseases, Whereas $57 \%$ of amputation were performed due to gangrene or infection in amputees ${ }^{4}$. Other researchers suggest that $45-70 \%$ of amputations were as a result of diabetes mellitus, 13 times greater than all non-traumatic causes $^{3,4}$. However same results were yielded by another research conducted by Indian diabetic pmputation study group. Trauma was narrated as a 
main cause of upper limb amputation in numerous researches conducted at southern Finland and Denmark $^{12,14}$.

However, as far as the site of amputation is concerned studies showed different results, but lower-limb amputations account for 97 percent of all dysvascular limb loss discharges from hospital ${ }^{4,8,9}$. Glattly (1964) conducted a survey of 12,000 new amputees over the 1961-1963 period in the USA and found a predominance of trans-tabial amputees among the lower limb prosthesis users ${ }^{10}$. Jones (1989) also found that trans-tibial prostheses made up to $58.7 \%$ of all prostheses prescribed under the free limb schemes in Australia (1981-1985) ${ }^{20}$. In another study by Katrak and Baggott (1980), it was shown that trans-tibial amputations were more common than trans-hemural amputations in Australia ${ }^{13}$. Children were predominant users of Syme's and trans-radial prostheses. The hospital of the International Committee of the Red Cross Afghanistan in 1993 reported 2041 war injured patients mostly below knee amputees ${ }^{11}$.

Currently local studies for incidence of Amputations have been limited. The differences between studies in causes, presentation of rates, and level of amputation make meaningful comparisons impossible. Hence accurate, up-to-date, and comparable information on the incidence of amputations is required. Therefore this study has been conducted with the aim to determine the epidemiology of amputations in low resource community, so that a better prevention and rehabilitation plan could be made.

\section{METHODOLOGY}

This study was an observational, descriptive study conducted at Outpatients Department of Institute of Physical Medicine and Rehabilitation (IPMR), Dow University of Health Sciences, Karachi, Pakistan from October 2007 to June 2012. All patients seeking rehabilitation advice for prosthetic fitting were included in the study through non probability purposive sampling. A detailed history was taken along with, physical examination, laboratory tests and radiological examinations. A Performa was prepared to collect all possible amputee information including Patient age, occupation, stump complications, side of amputation, level of amputation and associated risk factors of amputation. Patients were given pre prosthetic counseling, prosthesis, pre and post prosthesis physiotherapy in outpatients department. All patients were followed for their prosthesis and prognosis. The amputees included both male and female from all over Sindh. The frequency and determinants were recorded to evaluate causes and level of amputations; Data was entered and analyzed on SPSS version window version 15.

\section{RESULTS}

This study presents precise data on epidemiology of amputation in low resource community, Sindh, Pakistan. The data analyses of 1115 cases were performed on SPSS windows version 16 during period from Oct 2007 to June 2012. All patients seeking rehabilitation assistance for prosthesis fitting were analyzed at IPM\&R, Dow University of Health Sciences Karachi, Pakistan. The characteristics of amputees have been shown in Table-I. While Table- II shows the mean age and SD of all the patients enrolled in this study, Table-III and Table IV shows the level and cause of amputation respectively.

\begin{tabular}{|c|c|c|}
\hline Gender & No. of Participants & $\%$ age \\
\hline Male & 932 & $83.58 \%$ \\
\hline Female & 183 & $16.41 \%$ \\
\hline \multicolumn{2}{|c|}{ Table-l. } \\
\hline
\end{tabular}

\section{DISCUSSION}

Increasing amputation rate is a serious problem globally and also in our country due to road traffic accidents, industrialization, agriculture related injuries, medical conditions, terrorist attacks, earth quake, bomb blasts, and weapons. 


\begin{tabular}{|c|c|c|c|c|c|}
\hline & N & Minimum & Maximum & Mean & Std. Deviation \\
\hline Age & 1115 & 2 & 95 & 38.40 & 17.386 \\
\hline
\end{tabular}

Table-ll.

\begin{tabular}{|l|c|c|}
\hline \multicolumn{1}{|c|}{ Level of Amputation } & $\begin{array}{c}\text { No. of participants } \\
\text { (frequency) }\end{array}$ & \% age \\
\hline Transtibial & 528 & $47.35 \%$ \\
\hline Transfemoral & 312 & $27.98 \%$ \\
\hline transradial & 83 & $7.4 \%$ \\
\hline Transhumeral & 62 & $5.56 \%$ \\
\hline Shoulder disarticulation & 8 & $0.71 \%$ \\
\hline Hip disarticulation & 11 & $0.98 \%$ \\
\hline Knee disarticulation & 17 & $0.63 \%$ \\
\hline Others & 94 & $84 \%$ \\
\hline & & \\
\hline
\end{tabular}

\begin{tabular}{|l|c|c|}
\hline \multicolumn{1}{|c|}{ Cause of Amputation } & Frequency & \%age \\
\hline Road Traffic Accident & 428 & $38.38 \%$ \\
\hline Diabetes & 172 & $15.42 \%$ \\
\hline Infection & 159 & $14.26 \%$ \\
\hline trauma & 138 & $12.37 \%$ \\
\hline Tumor & 67 & $6 \%$ \\
\hline Gunshot Injury & 32 & $2.86 \%$ \\
\hline Bomb Blast Injury & 15 & $1.34 \%$ \\
\hline Congenital & 51 & $4.57 \%$ \\
\hline Burns & 39 & $3.49 \%$ \\
\hline Earth quake & 07 & $0.62 \%$ \\
\hline Others & 07 & $0.62 \%$ \\
\hline
\end{tabular}

Table-IV.
The overall male to female ratio was approximately $7: 1$, males are more susceptible to amputation due to road traffic accidents and work accidents as women normally in our culture do not do the mechanical work and they drive occasionally too.

The mean age of amputees was 38years \pm 17.38 ; the results are different from the different studies conducted in Australia, America and Saudi Arabia, in Australia and America the mean age of amputees were older than the mean age of amputees in Saudi Arabia and in Pakistan. ${ }^{(8)}$ This reflects predominantly younger age pattern of the Pakistani population due to trauma $(50.75 \%)$, the majority of these injuries were associated with road traffic accidents (38.38\%) and occupational hazards (12.37\%), showing that in our country safety rules are generally not practiced.

The proportion of diabetic amputees varies across the different regions, 17.3\% in England (Harris et al 1974), $61 \%$ in Netherlands (Boontje 1988), 58\% in Nigeria and $75 \%$ in India. ${ }^{(17,18)}$ The results of the current study suggest the rate of amputation due to in Sindh, Pakistan is $(15.42 \%)$ andit is possible to prevent dysvascular lower limb amputation by earlier detection and good diabetic control. ${ }^{(19)}$ (Larsson and Risberg, 1988). A review of amputation statistics by Jonssonet al. (1984) on amputations in diabetic patients in Gotland and Umea countries 1971-1980 showed that a lower occurrence of amputation in Umea was because of early detection of gangrene and its management ${ }^{22}$.

In our study population $14.26 \%$ cases were due to infections. Normally, surgeons treat advanced infections through antibiotics, drainage, removal of infected tissue or surgery to increase the blood flow to the affected area, if these options do not work, and tissue damage is progressing, then amputation is only choice to remove a source of infection and save 
patient's life.

There were also reported cases of amputation due to tumor (6\%), congenital (4.57\%), Gunshot injuries (2.86\%), bomb blast injuries (1.34\%) and others.

Moreover, lower limb amputations (75.33\%) were more common in low resource community than upper $\operatorname{limb}(12.96 \%)$. Further data analysis showed that trans-tibial amputations (47.35\%) as compared to trans-femoral $(27.98 \%)$ were more common; these results could be correlated with the number of other researches conducted in different countries ${ }^{8}$. The possible reason for transtibial amputation is that surgeons try to save the knee on the affected side leading to higher rate of trans-tibial amputees.

In upper limb amputation trans-radial amputations (7.4\%) were more than trans-humeral (5.56\%), Sturupet al. (1988) and Jones (1989) also found that trans-radial prostheses were the commonest upper limb prostheses ${ }^{15,16}$. Studies indicates that upper limb amputations mostly resulting from trauma especially machine injuries are expected to occur more frequently in the dominant limb. A case series carried out at Pakistan Institute of Medical Sciences Hospital, Islamabad $^{16}$ in 2009 reported that $38.4 \%$ traumatic hand amputees were machine operators and $12.3 \%$ were labourers. The most commonly reported machines were electrically powered saws, Chara cutting and press machines ${ }^{21}$.

Other less common sites of amputation were shoulder disarticulation $(0.71 \%)$, through knee $(0.63 \%)$ and hip disarticulation (0.98\%).

\section{CONCLUSIONS}

The overall impression of the study states that the common causes of amputation are avoidable and could be reduced by appropriate primary and secondary preventive measures. Since, in Pakistan, trauma is the leading cause of the amputation of upper and lower limb, as shown in this study, it is recommended to provide better medical and surgical care for trauma along with implementation of safety protocols and guidelines to reduce the incidence of road traffic accident and occupational hazards.

The present study should be extended to the national level to include more data for causes and level of amputations and this is possible only through comprehensive surveys 0 reliable statistics from different centres in Pakistan to plan the provision of better facilities.

Copyright(C) 15 Jan, 2013.

\section{REFERENCES}

1. Abou-Zamzam AM, Jr., Teruya TH, Killeen JD, Ballard $\mathrm{JL}$. Major lower extremity amputation in an academic vascular center. Ann Vasc Surg. 2003 Jan;17(1):8690.

2. Aragon-Sanchez J, Garcia-Rojas A, Lazaro-Martinez $\mathrm{JL}$, Quintana-Marrero Y, Maynar-Moliner M, Rabellino $M$, et al. Epidemiology of diabetes-related lower extremity amputations in Gran Canaria, Canary Islands (Spain). Diabetes Res ClinPract. 2009 0ct;86(1):6-8.

3. World Report on Disability 2011. World health organization and World Bank. WHO Library Cataloguing-in-Publication Data.

4. National Limb Loss Information Centre Fact Sheet, Amputation Statistics by Cause Limb Loss in the United States, Revised 2008 (reviewed on October 14, 2011).

5. Kathryn Ziegler-Graham, PhD, et al. "Estimating the Prevalence of Limb Loss in the United States - 2005 to 2050," Archives of Physical Medicine and Rehabilitation 89 (2008): 422-29.

6. Patricia F. Adams, et al, "Current Estimates from the National Health Interview Survey, 1996," Vital and Health Statistics 10:200 (1999).

7. Timothy R. Dillingham, MD, et al, "Limb Amputation and Limb Deficiency: Epidemiology and Recent Trends in the United States," Southern Medical Journal 95 (2002): 875-83. 
8. H. S. AL-TURAIKI and L. A. A. AL-FALAHI, Amputee population in the Kingdom of Saudi Arabia. Prosthetics and Orthotics International. 1993; 17: 14756.

9. Burgess Em. The below-knee amputation ICIB, 1969;8(4):1-22.

10. GlattlyHw.A statistical study of 2,000 new amputees. South Med J.1964; 57:1373-78.

11. Hansson J. The leg amputee: a clinical follow up study. ActaOrthop Scand.1964;(Suppl) 35 (Suppl 69):104.

12. Anderson R, Ebskov B (1988). Trends in lower extremity amputations (Denmark 1978-83) In: Amputation surgery and lower limb prosthetics. / edited by Murdoch G, Donovan R.-Oxford, Blackwell Scientific, p3-8.

13. KatrakPH, Baggot JB. Rehabilitation of elderly lower extremity amputees. Med J Aust1980;(1):651-53.

14. Pohjolainen $\mathrm{T}$, AlarantaH. Lower limb amputations in Southern Finland 1984-1985. Prosthet Orthotlnt: 1 (2): 9-18.

15. Sturup J, ThyregodHc, Jensen Js, RetpenJb,Boberg G, Rasmussen $E$, Jensen $S$ et al. Traumatic amputations of the upper limb: the useof body-powered prostheses and employment consequences. ProsthetOrthot Int.1988;1(2): 50-52.
16. Jones LE. Amputee Rehabilitation: basic principles in prosthetic assessment and fitting - part 1. Med J Aust 27 1977; Aug, 290-93.

17. Udosen AM, Ikpeme IA, Etiuma A, Egor S. Major amputations at the University of Calabar Teaching Hospital, Calabar, Nigeria. NigJ Surg Sciences 2004; 14:60-3.

18. N E Ngim, W 0 Ndifon, A M Udosen, I A Ikpeme, and E Isiwele. Lower limb amputation in diabetic foot disease: experience in a tertiary hospital in southern Nigeria African Journal of Diabetes Medicine. May 2012; 20(1)13-23.

19. Larsson PA, Risberg B. Amputations due to lower-limb ischemia. ActaChirScand1988; 154:267-70.

20. Jones LE. Prosthetic limb use in Australia 1981-1985 under the Free Limb Scheme. ProsthetOrthot Int,1989; 13:76-81.

21. Sidra Shabbir et al, Outcome of Vascular Trauma at Pakistan Institute of Medical Sciences, Islamabad: Ann. Pak. Inst. Med. Sci. 2011; 7(1): 29-32.

22. Lindegård $\mathrm{P}$, Jonsson $\mathrm{B}$, Lithner $\mathrm{F}$., Amputations in diabetic patients in Gotland and Umeå counties 1971 . 1980: Acta Med Scand Suppl. 1984;687:89-93.

\section{AUTHOR(S):}

1. DR. NABILA SOOMRO

Head of the Department

Institute of Physical Medicine and Rehabilitation

Dow University of Health Sciences

2. RUKHSANA BIBI

Clinical Psychologist

Institute of Physical Medicine and Rehabilitation

Dow University of health sciences

3. DR. SYED IMRAN AHMED

AssistantProfessor

Institute of Physical Medicine and Rehabilitation

Dow University of health sciences

4. Brigitte Kamran

Sr. Lecturer Occupational Therapy

Institute of Physical Medicine and Rehabilitation

Dow University of health sciences
5. Muhammad Ali Minhas

Physiotherapist Prosthetic \& Orthotics

Institute of Physical Medicine and Rehabilitation Dow University of health sciences

6. Kamran Yousuf Siddiqui Manager / Sr. Lecturer (Prosthetics \& Otrthotics) Institute of Physical Medicine and Rehabilitation Dow University of health sciences

Correspondence Address:

Dr. Nabila Soomro

Head of the Department

Institute of Physical Medicine and Rehabilitation

Dow University of Health Sciences

Nabila61@gmail.com

Article received on: 01/12/2012

Accepted for Publication: 15/01/2013 Received after proof reading: 03/02/2013 